\title{
THE SIGNIFICANCE OF POTATO VIRUS DISEASES IN FINLAND.
}

\author{
By \\ E. A. Jamalainen.
}

Department of Plant Pathology of the Agricultural Experiment Station, Tikkurila.

Received 15. VI. 1946.

Information about the distribution of potato virus diseases in different countries show that the injuries caused by these diseases are negligible in regions with a cold and raw climate (cf. 5, 12, 19). The injuries caused by the most dangerous virus diseases are, again, proportional to the insects spreading them, particularly the aphids, so that the climatic and other factors preventing their appearance are at the same time an obstacle to larger injuries of virus diseases (cf. 1, 5, 7, 12). Such regions where the significance of potato virus diseases is small are countries in the northern parts of the globe, such as Norway, North Scotland, Canada, and Alaska. Virus diseases appear in a limited scale also in Esthonia, in the coastal regions of Holland, in North-east and Eastern Germany, in Sweden excluding the south part of the country $(10,11)$, and in the mountain regions of different countries.

On account of its geographical situation Finland should belong to such countries where the significance of potato virus diseases is small, and as will be shown in the following, that is really the case in a great part of the country. ${ }^{1}$ The following presentation is based principally on information received from institutions performing experiments on the potato in different parts of the country.

1 Owing to climatic conditions the period of potato growth in Finland is quite short. Even in the southern parts of the country it does not exceed four months, being in the central parts from 3 to $3 \frac{1}{2}$ months and in the nothern parts from $2 \frac{1}{2}$ to 3 months only. Due to spring frost potato is planted in South Finland first usually in the beginning of June, and in the central and northern parts of the country in the middle of June. The autumn frosts often freeze the potato stems even in South Finland already in the middle of September and in the other parts of the country still earlier. The average temperature in June in the southern parts of the country is $13-14^{\circ} \mathrm{C}$, in the central parts $12-13^{\circ}$, and in the northern parts where potato can still be grown, $10-11^{\circ}$; in July $16-17^{\circ}, 15-16^{\circ}$ and $13-15^{\circ}$, respectively, and in August $14-15^{\circ}, 13-14^{\circ}$ and $10-12^{\circ}$, respectively. In spite of the shortness and chillness of the period of its growth potato is cultivated in Finland even in the far north and in SouthernLapland, and to a smaller extent also in other parts of Lapland. The $\mathrm{n}$ rrthern boundary for potato cultivation lies at about $69^{\circ}$ latitude. 


\section{On the occurrence of potato virus diseases in Finland.}

The Department of Plant Pathology of the central Agricultural Experiment Station in Tikkurila near Helsinki, attached more importance to the virus diseases of the potato for the first time in 1924, when varieties immune to wart disease had been procured for the Department for experimental purposes from foreign countries, principally from Germany and England. The potato material proved to be very affected by virus diseases. When the experiments were continued in 1925 it was verified that virus diseases appeared stronger than before in all plants grown from diseased potato tubers. The results of the 1925 experiments will be presented in the following Table. In many of the varieties a great part of the individuals were affected by leaf roll. Many varieties showed in addition, plenty of other virus diseases, viz. mild mosaic, crinkle and streak. Aucuba mosaic appeared most in the Ceres varieties. The experiments were continued in 1926, when the crops of most

Virus diseases of foreign potato varieties according to the experiments of the Department of Plant Pathology in 1925 .

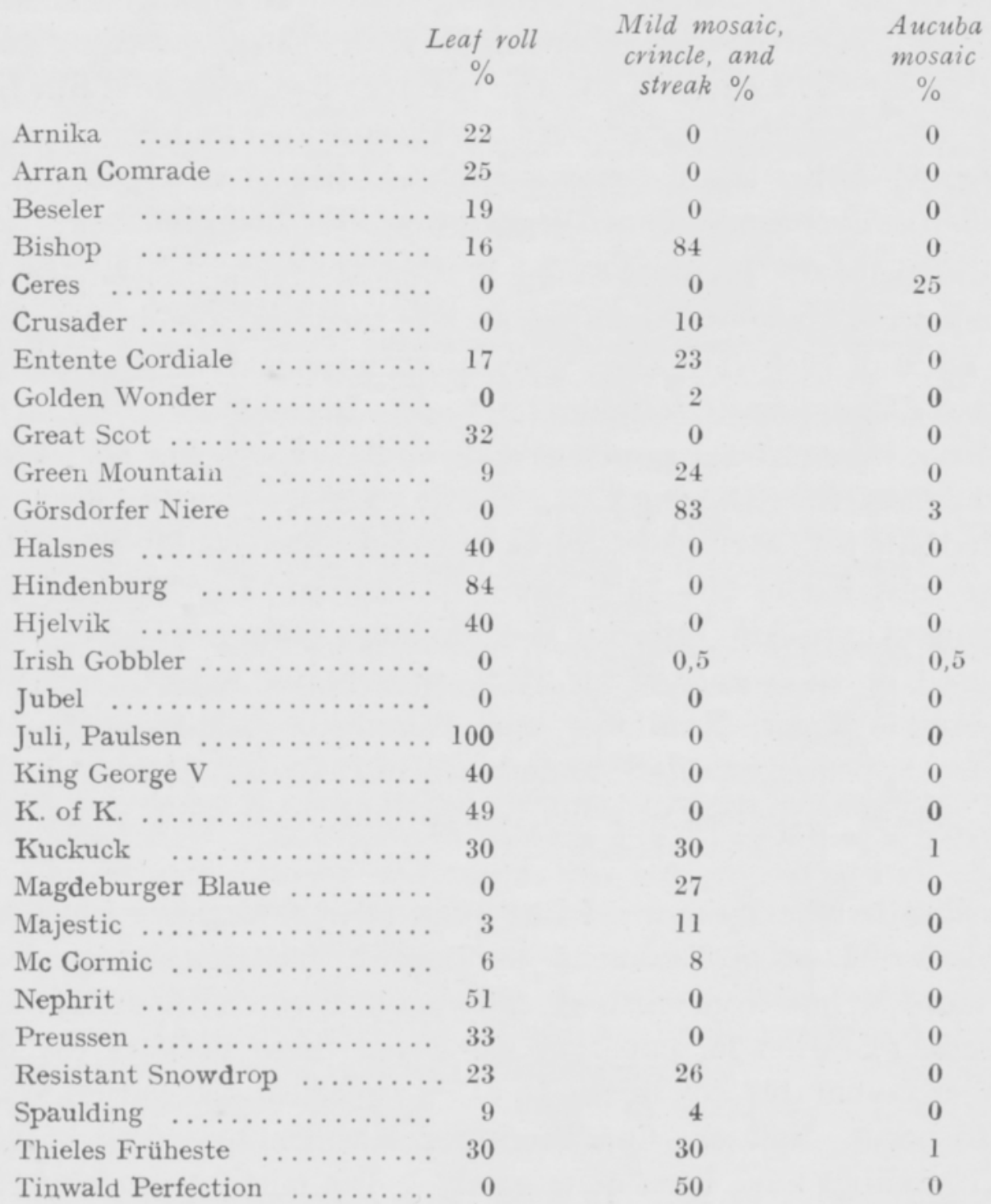


of the plants affected from leaf roll were quite insignificant, with only a few small tubers on poorly developed vines.

At the Department of Plant Pathology potato virus diseases have been continuously observed, and it has been verified that especially in potatoes brought from foreign countries virus diseases occur plentifully, e.g. in 1945, when the Department carried out experiments with a number of potato varieties obtained from Sweden. Many of these were considerably affected by mild mosaic, crinkle and streak.

The Department of Plant Pathology, where information about plant diseases is sent from different parts of Finland, has received in general comparatively scanty information regarding the virus diseases of potato, which shows that farmers haven't considered injuries caused by them conspicuously large.

According to observations on the potato plantation of the Agricultural Experiment Station's estate and on the surrounding potato fields at Tikkurila, the amount of virus diseases has there been very small.

The experiments with potato varieties carried out by the Department of Plant Cultivation of the Agricultural Experiment station at Tikkurila in 1942 show that virus diseases appeared more abundantly than usual, according to information presented to Mr. V. LÄHDE, M. A. The potatoes had both mild mosaic and crinkle and streak; most heavily infected were the Eigenheimer and Bintje varieties. Rosafolia was, on the other hand, almost completely free of virus diseases, and also the varieties Ben Lomond and Paul Wagner were but little infected.

At Tammisto, the Plant Breeding Station of Hankkija near Helsinki, detailed observations were made on the appearance of virus diseases in potato experiments in 1939-43 and 1945 (3). The observations were presented as the percentage of virus diseased individuals (crinkle + streak). Individuals affected by virus diseases were not removed, the potato-crop from the experiment of the preceding year being used as seed the following year. The Juli variety was during the whole experiment period (1939-1942) 100\% virus diseased. More badly virus diseased, with an average infection of $20-35 \%$, were in addition, the Eigenheimer, Frühgold, Goldwährung, Up-to-date, Bintje, and Magnum bonum varieties. More slightly virus diseased, on an average of 3 to $10 \%$, were Flava, King George V, Konsuragis, Ostbote, Paul Wagner, Rosafolia, and Tammiston aikainen (Early Tammisto). Virus diseases appeared especially abundantly in 1941-42. During other observation years the potato varieties, with few exceptions, were only a few percent virus diseased.

According to the opinion of Brummer (3), the decisive cause of the appearance of virus diseases at Tammisto has been the fact that foreign potato varieties suffering more or less from virus diseases have been continuously brought to the Plant Breeding Station for experiments. From these varietes the diseases have spread under favourable conditions to other experimented varieties that are susceptible to virus diseases. Conditions for a wider spreading of virus diseases to the surroundings have been quite small at Tammisto, to conclude from the fact 
that usually little virus diseases have appeared on the potato cultivations of the Station's farm.

From other experimenting organizations the following information has been received in 1946 about potato virus diseases.

Miss Helvi Eskola, M. A. of the Plant Breeding Department of the Agricultural Experiment Station at Jokioinen, about $70 \mathrm{~km}$. nort-east of Turku, informs the author that virus diseases have appeared comparatively little in variety experiments in $1942-45$ during which period more detailed observations have been made about these diseases. The varieties Rosafolia. Tammiston aikainen. Ostbote, King George V, and Eldorado have been almost totally free from virus diseases all these years, and even in varieties contaminated by virus diseases, e.g. Eigenheimer, Goldwährung, Frühgold, Möve, and Kalev, only a few per cent virus infected could be verified. Also on the potato cultivations of the Jokioinen estate, and on the other potato fields of the locality, virus diseases have appeared on a small scale.

Mr. V. Kallio, M. A., of the Garden Department of the Agricultural Experiment Station at Piikkiö, about $15 \mathrm{~km}$. east of Turku, states that in experiments on potato varieties Victor and Juli potatoes have been especially virus diseased, also in the Vesijärvi and Early Puritan varieties these diseases have occurred quite abundantly, and to some extent in the Tammiston aikainen. The early varieties seem to be more susceptible to virus diseases than the late ones. The potato viruses have been found to appear also on the surrounding potato cultivations.

From Mr. P. Jalkanen, M. A., of the Plant Cultivation Experiment Station (of North Tavastland) at Pälkäne, about $35 \mathrm{~km}$. south-east of Tampere, comes the report that on account of virus diseases some of the best cooking potato varieties, e.g. Preussen, Edda, and Goldwährung have had to be abandoned. Besides in variety experiments, virus diseases have appeared abundantly on the domestic cultivations, where they have increased in amount from year to year especially in the above mentioned varieties. The early varieties seem to be especially susceptible to reaction.' Ostbote is one of the few varieties which has remained for many years obviously completely free from virus diseases.

Mr. H. Meurman, M. A., of the Carelian Plant Cultivation Experiment Station at Anjala, situated about $30 \mathrm{~km}$. north of Kotka, states that virus diseases, streak and crinkle have been verified to appear in potato variety experiments. In 1942 when detailed observations were made, the varieties Eigenheimer, Vesijärvi and Kalev were found to be most acceptable to virus diseases (15-32\% infected individuals); many other varieties, e.g. Ostbote, Ben Lomond, Tammiston aikainen, and Rosafolia were completely free from virus dieseases. Virus diseases have been verified to occur on the domestic cultivations of the Experiment Station, but they had, however, no marked effect on the crops. Virus diseases seem, for the present, to be of very little practical importance to the potato cultivations surrounding the Experiment Station.

Mr. Y. K. Koskinen, M. A., of the South Savo Plant Cultivation Experiment Station, which is situated at Karila, near Mikkeli, reports that virus diseases have not appeared to an extent worth mentioning especially during the last years. It seems as if virus diseases have appeared somewhat more abundantly during years with dry summers than in normal years, and in years rainier than normal. According to observations the Juli and Prof. Edler varieties have been more susceptible to diseases. On the near surroundings of the Experiment Station and in the whole district the case probably is the same. No announcements concering virus diseases have been received by the Experiment Station, nor can these be considered to have much significance to potato cultivation in the locality.

Mr. M. Salminen, M. A., of the North Savo Plant Cultivation Experiment Station at Maaninka, about $45 \mathrm{~km}$. north-west of Kuopio, states that virus diseases have not noticeably appeared on the local potato cultivations. This is partly due to the fact that virus resistant varieties are generally cultivated. In experiments at the Station on varieties, the seeds of which have been brought from elsewhere, virus diseases have been verified to appear in almost all cases. Rosafolia potato has proved to be very resistant against virus diseases. The Goldwährung variety, on the other hand, seems to be susceptible to virus diseases. 
From Mr. L. Salohermo, M. A., of the Finnish Bog Cultivation Society's Experiment Station at Tohmajärvi, in Karelia, about $60 \mathrm{~km}$. south-east of Joensuu, comes the following report: The Experiment Station does not possess accurate information abcut the appearance of virus diseases. On the domestic plantations of the Experiment Station virus diseases have been very scarce and they have not appeared to any noteworthy degree in experiments. Virus diseases, in general, evidently occur in a quite limited amount in the lccality.

From. Mr. T. Honkavaara, M. A., of the South Pohjanmaa Plant Cultivation Experiment Station at Ylistaro, abount $50 \mathrm{~km}$. of Vaasa the following report has been received: No special virus years have been noticed in the locality. In 1945 they have not occurred very much, anyhow. The occurrence of virus diseases in the locality is probably very limited, and it has no considerable significance for potato cultivation. This is partly due to the fact, that the Rosafolia potato is generally cultivated in the locality, which is not susceptible to virus diseases. Also Eigenheimer and Vesijärvi varieties are cultivated abundantly in the locality, but owing to the lack of observations nothing can be said as to how much virus diseases they have developed. Not very much virus diseases appear in the experimental potato crops of 1945. On the other hand, viruses appeared considerably in experiments during the warm summers of $1936-38$, being quite abundant in Prof. Edler varieties. The virus diseases in general have been spread throungh the experimental potato seed.

Mr. O. Antrinen, M. A., of the North Pohjanmaa Plant Cultivation Experiment Station at Ruukki, about $45 \mathrm{~km}$. south-west of Oulu communicates that virus diseases have not occurred in the potato varieties of the Experiment Station to an extent causing them to be seriously considered and having any significance to the crops. No virus diseases have occurred on the potato cultivations of the Experiment Station nor have they been reported elsewhere in the locality.

Mr. S. A. RankamaA, M. A., of the far northern Plant Cultivation Experiment Station at Apukka near Rovaniemi, informs the author that his only case was in 1942 when the Green Mountain variety, the seed of which had been brought from elsewhere, developed a few individual cases of crinkle virus. The diseased potatoes were not used for seed purpores. Since then no virus diseases have occurred in experiments in this or any other variety of potato, nor have they been met with elsewhere in the locality.

Information about virus diseases has been received also from the Board of Agriculture, which collects these facts from the monthly reports on the condition of vegetation supplied by the district councillors from different parts of the country. According to this information virus diseases have been verified to occur in 1945 in many communities of the provinces of Turku and Pori, Uusimaa, and Häme. Virus diseases, on the other hand, have been reported only accidentally in 1 or 2 communities of the other provinces.

Weather conditions are shown to have a significant effect on the appearance of virus diseàses in Finland, as in other countries. Brummer (3) mentions that when weather conditions in the 30 's and early 40 's vere favourable, owing to warm, dry summers, to the spread of virus diseases, very favourable conditions resulted for the occurrence of degeneration disease in potatoes at the Tammisto Plant Breeding Station. When the weather conditions changed a few years ago and the summers became cooler and wetter again, there was quite a considerable reduction in the occurrence of virus diseases in the tests. Similar reports have been received from other experimental establishments, as was seen above.

\section{Types of virus diseases of potatoes in Finland.}

Of potato virus diseases met with in Finland mild mosaic, streak, and crinkle are worth mentioning. The injury caused by mild mosaic in Finland as well as in 
other countries is small. Greater injury is caused by streak when this appears more abundantly $(2,3,15)$.

One could have presumed, that the leaf roll would have spread to other potato cultivations at the Agricultural Experiment Station in Tikkurila during the period of its abundancy in the variety experiments of $1924-26$ carried out by the Department of Plant Pathology, as described above. However, this did not happen and the other potato cultivations of the Agricultural Experiment Station remained continuously free from leaf roll and from Aucuba mosaic as well. No information about leaf roll has been received from farmers from other parts of Finland or from Experiment Stations, that would show the disease having any greater signiificance in our country. Apparently the leaf roll, which in many countries is one of the worst virus plagues of the potato, is in Finland practically insignificant. The same can be said about Aucuba mosaic.

\section{Economic significance of virus diseases of potatoes in Finland.}

The information presented above about potato viruses shows that they are found in Finland chiefly in the southern parts of the country, most abundantly in the provinces of Turku and Pori, Uusimaa, and Häme. In other parts of Finland the virus diseases do not seem to have any significance worth mentioning. Even in the southern parts of the country the injuries of virus diseases are of no great importance. They do not even there cause the degeneration of potato in the same sense of meaning as in many other potato cultivating countries, where the seed potato in many regions must be changed regularly every year or least after $2-3$ year intervals into new seed free from virus diseases.

What has been said before refers to regular potato cultivations. At the Experiment Institutions and Stations virus diseases may appear abundantly, as we saw from the above. This is due chiefly to the fact that new potato-seed which is more or less diseased by virus has been continuously brought in from foreign countries, and through this seed the diseases in turn have been able to spread into other experimental varieties. The spreading of virus diseases through experiments more widely to the surroundings has not, according to present information, happened to any greater extent.

\section{Susceptibility to virus diseases of varieties of potato grown in Finland.}

The information received from different experiment organisations about the resistance of potato varieties toward virus diseases show that Rosafolia has been throughout the whole country particularly well resistant against virus diseases. ${ }^{1}$

1 The most cultivated potato variety in Finland is Rosafolia (Pommersche Saatzuchtgesellschaft), which covered $25 \%$ of the potato acreage in 1945. Next came Vesijärvi-Harbinger (Sutton \& Sons), Magnum bonum (Sutton \& Sons), Up-to-date (A. Findlay), and Eigenheimer (Veenhuizen) (according to Kinnunen, 8). Other more commonly cultivated varietes are Eldorado (A. Findlay), Ben Lomond (Aikman Patton), Paul Wagner (Pommersche Saatzuchgesellsch.), King George V (Butler), Deodara 
It has been almost completely free from virus diseases at most Experiment Institutions and Stations. As to the virus diseases, also the Tammiston aikainen, King George V, Ostbote, and Paul Wagner varieties according to observations, have been perfect or only slightly suspectible to diseases. Where the virus diseases, streak and crinkle, in experiments have appeared more abundantly, the early varieties, especially Juli, Prof. Edler, and Vesijärvi have been susceptible to diseases. The other varieties most susceptible to these diseases were found to be Frühgold, Eigenheimer, Goldwährung, Magnum bonum, Preussen, and Up-to-date.

\section{Possibilities of exporting virus-free seed potatoes from Finland.}

Seed potatoes free from virus diseases have in some countries become an important export article to such countries where virus diseases are found abundantly. Such potato exporting countries are, e.g. Esthonia, Holland, Alaska, and Canada. Finland also should have good innate qualifications to start the cultivation of seed potatoes free from virus diseases for export to such countries where there is a great demand for this sort of goods. At least the central and northern parts of Finland ought to very suitable for the producing of seed potatoes free from virus diseases.

In Finland the examination of seed potatoes offered for sale is defined officially by statutes and orders. In a decree by the Ministry of Agriculture of August 31st, 1945 (18) concering the demands for quality of seed potatoes, the seed is divided into three classes: selected, quality, and commercial brands. Selected seed must be field examined, being allowed to contain irrelevant strange individuals $1 \%$ at most. Wart disease and nematode are not allowed at all, and individuals suffering from virus diseases except mild mosaic are allowed to at most $0,2 \%$, likewise individuals suffering from Verticillium-wilt. Black leg and black scurf (Rhizoctonia solani KüHN) are allowed to total at most $4 \%$. In addition the purity of variety, the amount of disease, the grade of assortment and other quality requirements of seed potatoes are determined, in addition, by laboratory examinations. With these examinations as a basis Finland has possibilities to produce seed potatoes that will fulfil the requirements made in other countries. The law of import, export, and trade of seed plant from April 9th, 1937 (17) gives, again, the officials the right to supervise that no illegality may happen in the export of potatoes.

(v. Kameke), Great Scot (Mc Alister), Tammiston aikainen (improvement of Tammisto Plant Breeding Station), Majestic (A. Findlay), Early Rose (American origin), and Early Puritan (American origin). Domestic varieties are cultivated in considerable amounts, especially in the northern parts of the country.

Experiments are carried out at present at the Experiment Institutions and Stations with a number of potato varieties the cultivation of which will be made general, as far as they prove to be fit for conditions in Finland. Of these the following can be mentioned: Ackersegen (Böhm), Agnes (v. Zwehl), Aqvila (v. Dürckheim), Bintje (De Bries), Direktor Johansson (Modrow), Express (Veenhuizen), Flava (Pommerische Saatzuchtgesellsch.), Frühnudel (Knehdener Pflanzenzucht), Golden Wonder (John Brown), Goldwährung (Muttriner), Johanna (Böhm), Merkur (Pommersche Saatzuchtgesell.), Mittelfrühe (Böhm), Olympia (v. Kameke), Ostbote (Raddatz), and Sieglinde (Böhm). 


\section{Significance of insects as vectors of potato virus diseases in Finland.}

As has been mentioned in the beginning, aphids, especially the peach aphis (Myzodes persicae Sulz.), are the most important vectors of virus diseases. Viruses spread by Myzodes persicae in Europe (cf. 1, 5, 7, 12, 16), are Solanum virus 14, which causes leaf roll, Solanum virus 2 (the cause of streak), Solanum virus 3 (together with Solanum virus 1 causes crinkle) and Solanum virus 9 (the cause of Aucuba mosaic). The conditions in which Solanum virus 1, the cause of mild mosaic, spreads are not wholly known. According to certain information it spreads chiefly by sap inoculation, others, on the other hand, take a doubtful stand in this (5). According to some information Solanum virus 1 is spread by thrips. Aphids, on the other hand, do not appear as vectors of this virus.

According to Heinze and Proff T (7, p. 145), in Germany only Myzodes persicae and Aulacorthum (Myzus) psendosolani ТнЕов. are able to spread virus diseases in the field. According to LEAcH (9) the Doralis (Aphis) rhamni Boyer de Fonsc. spreads Solanum virus 3. According to some other investigations (cf. 1, 17) potato viruses may be spread also by other species of aphids, and by some species of psyllids, leafhoppers, thrips, and Lygus spp.

Experiments performed in Sweden (OssianniLsson, 13) show that Myzodes persicae is found, in addition to southern Sweden, also in other parts of the country; the northernmost occurrence being $63^{\circ} 15^{\prime} \mathrm{N}$. lat. OssiannILsson shows in a later publication (14) that this aphis is found on different greenhouse plants in different parts of the country where it can hibernate. In the same experiments the occurrence of other insects spreading potato viruses is also accounted for.

Myzodes persicae is known also on Finland. HeIKINHE IMo mentions in his paper of 1944 (6), that Phrodon (Myzodes) persicae is found in Finland chiefly on greenhouse plants. According to this publication the first information about this species is from 1912, the insect being found on Hibiscus in Helsinki. In this and in other localities in Uusimaa Myzodes persicae has been found later many times on different greenhouse flowers and vegetables. Mr. V. Kanervo, M. A., met with aphis in 1937 in the greenhouse of the Otava Farming School near Mikkeli (in Central Finland) on many different plants, as e.g. on potato. In $1945 \mathrm{Mr}$. O. He IKINHEImo, according to a communication to the writer observed this aphis on many greenhouse plants at the University Botanical Garden in Helsinki.

The present knowledge about Myzodes persicae is insufficient to give a clear picture of the distribution of this species on our country, still less would it allow any conclusion to be made about the significance of this aphis as the vector of potato viruses. It is known, however, that Myzodes persicae is found here, as well as in Sweden, chiefly on greenhouse plants, where it has possibilities to hiber. nate. The peach and apricot trees, where the aphis lays its eggs, are such a great rarity even in greenhouses in Finland, that they can play no part as spreaders of this species. The hibernation of Myzodes persicae on Brassica species, which is possible in Wales (4), cannot come into question in Finland because cabbage species that retain their greenness over winter are not cultivated here. 
Among other aphids that are found in the potato cultivations of this country and which, according to information available in literature, can spread potato viruses, the following may be mentioned: Doralis rhamni Boyer de Fonsc., Neomyzus circumflecsus BuckTon and Aulacorthum sp. (probably A. solani Kalt., which is considered a synonym of $A$. pseudosolani Tнеов.). Of these, Doralis rhamni is mentioned in the publication of 1944 (6), and information about other species has been received recently from Mr. Heikinheimo. Among other potato insects which appear abundantly in potato fields in Finland and which may come into question as vectors of potato viruses, Empoasca (Chlorita) flavescens F., which belongs to the leafhoppers, may be mentioned.

The occurrence of potato viruses in Finland as in other countries, must probably depend upon the aphids spreading them. Due to the cold climate and short period of growth prevailing in our country the qualifications for the increase of aphids spreading potato virus diseases anywhere in Finland and especially in the central and northern parts of the country are evidently smaller than in the more southern countries, and, accordingly, the possibilities of the spreading of virus diseases are also smaller.

\section{REFERENCES.}

1) Bawden, F. C. 1939 - Plant Viruses and Virus Diseases, p. 1-272. Chronica Botanica. LeidenHolland.

2) Brummer, Veikкo. 1940 - Millä tavoin virustaudit alentavat perunasatoa. Maan Suola, p. 142-143 and 145. Helsinki. (Finnish).

3) —— 1946 — Tutkimuksia tärkeimmistä Tammistossa esiint yreistä perunavirocseista. Har kkijan kasvinjalostuslaitos Tammisto, siemenjulkaisu 1946, p. 176-185. Helsinki. (Finnish).

4) Davies, W. Maldwyn 1934 - Studies on aphides infesting the potato crop II. Ann. Appl. Biol., $2 r$, p. $283-299$.

5) Hansen, Henning P. 1941 - Studier over Kartoffelviroser i Danmark III. Diss., p. 1-134. København. (Danish, with English Summary).

6) Heikinheimo, O. 1944 - Für die finnische Fauna neue Blattläuse (Hom., Aphidodea). Varlăufige Mitteilung. Annales Entomologici Fennici, IO, p. 1-7. Helsinki.

7) Heinze, K. \& Profft, J. 1940 - Ueber die an der Kartoffel lebenden Blattlausarten und ihren Massenwechsel im Zusammenhang mit dem Auftreten von Kartoffelvirosen. Mitteil. Biol. Reichsanst. Land.-- u. Forstw., Heft 6o, p. 1-164, Taf. I-IV.

8) Kinnunen, Erkki J. 1946 - Perunaviljelystiedustelun tuloksia. Koetoiminta ja käytäntö, 5, N:o 1, p. 6-8. Helsinki. (Finnish).

9) Leach, J. G. 1940 - Insect Transmission of Plant Diseases. New York and London. Ref. OssianNILSSON 1943, p. 32.

10) Linnell, D. 1943 - Om bladrullsjukans spridning i potatisfälten. Statens Växtskyddsnotiser, N:r 2, p. 6-11. Stockholm. (Swedish).

11) - — 1945 - Potatisviroserna och den skånska potatisodlingen. Statens Växtskyddsnotiser, N:r 3, p. 36-39. Stockholm. (Swedish).

12) Madsen, S. B. 1944 - Om Bekaempelse af Kartoflens Virussygdomme. Den Kgl. Veterinaer- og Landbohøjskoles Afdeling for Lantbrugets Plantedyrkning, 23, p. 1-85. (Danish, with English Summary). 
13) Ossiannilsson, Frej 1943 - Studier över de svenska potatisfältens insektfauna och dess betydelse för spridning av virussjukdomar I. Statens Växtskyddsanstalt, 39, p. 1-72. Stockholm. (Swedish, with German Summary).

14) —— 1944 — Virusbärare övervintra i växthus. Statens Växtskyddsnotiser, N:r 3, p.35-38. Stockholm. (Swedish).

15) Roivainen, H. 1943 - Perunan virustauteja torjumaan. Pellervo, 49, p. 534 -536. Helsinki. (Finnish).

16) Smith, Kenneth M. 1937 - A Textbook of Plant Virus Diseases, p. 1-615. London.

17) Laki siementavarain maahan tuonnista, maasta viennistä ja kaupasta. N:o 148, annettu Helsingissä 9 p:nä huhtik. 1937. (Finnish). Low of import, export, and trade of seed plant. No. 148, Helsinki, April 9th, 1937.

18) Maatalousministeriön päätös siemenperunan laatuvaatimuksista, N:o 869, annettu Helsingissä 31 p:nä elok. 1945. (Finnish). Decree by the Ministry of Acrigulture concernig the demands for quality of seed potatoes. No. 869, Helsinki, August 31st, 1945.

19) 18. Intern. Landwirtschaftskongress. Hauptberichte, Sektion IV, p. 11-15; Spezialberichte, Sektion IV, p. 15-63. Dresden 1939.

\section{SELOSTUS.}

PERUNAN VIRUSTAUTIEN MERKITYS SUOMESSA.

E. A. Jamalainen.

Maatalouskoelaitoksen kasvitautiosasto, Tikkurila.

Tiedot perunan virustautien levinneisyydestä eri maissa osoittavat, ettă näiden tautien aiheuttamat vahingot ovat vähäisimmät sellaisissa seuduissa, joissa vallitsee kylmä ja raaka ilmanala (vrt. $5,12,19)$. Vahingollisimpien virustautien tuhot ovat taasen suoranaisessa suhteessa niitä levittäviin hyönteisiin, lähinnä kirvoihin, siten että näiden esiintymistä ehkäisevät ilmasto- ym. tekijät ovat samalla esteenä virustautien suuremmille vahingoille (vrt. 1, 5, 7, 12). Sellaisia seutuja, joissa perunan virustautien merkitys on vähäinen, ovat lähinnä pohjoisosissa maapalloa sijaitsevat maat, kuten Norja, Pohjois-Skotlanti, Kanada ja Alaska. Virustauteja esiintyy vähän myös Virossa, Hollannin rannikkoseuduilla, koillis- ja itäosissa Saksaa, Ruotsissa, lukuunottamatta etelä-osaa maasta (10, 11) sekä eri maiden vuoristoseuduissa.

Suomen pitäisi kuulua maantieteellisen asemansa perusteella sellaisiin maihin, joissa perunan virustautien merkitys on vähäinen, ja kuten seuraavassa tullaan osoittamaan, siten onkin asianlaita suuressa osassa maata. Esitys perustuu päăasiallisesti niihin tietoihin, joita perunan virustaudeista on saatu perunakokeita suorittavilta koelaitoksilta ja koeasemilta.

Maatalouskoelaitoksen kasvitautiosastossa kiinnitettiin perunan virustauteihin ensimmäisen kerran suurempi huomio v. 1924, jolloin osastolle oli hankittu ulkomailta, pääasiallisesti Saksasta ja Englannista kokeiltavaksi joukko syövänkestäviä perunalajikkeita. Kokeiltava peruna-aineisto osoittautui hyvin virustautiseksi. Kokeita jatkettaessa v. 1925 todettiin virustautien esiintyvän entistä voimakkaampina kaikissa sairaista mukuloista kasvaneissa yksilöissä. Havainnot v. 1925 kokeista nähdään taulukosta siv. 135. Useissa lajikkeissa oli suuri osa yksilöistä kierreviroosin vaivaamia. Tämän ohella oli monissa lajikkeissa runsaasti muita virustauteja. Kokeita jatkettiin v. 1926, jolloin sato oli useimmissa kierreviroosia sairastavissa yksilöissä aivan mitätön, vain muutamia perunan alkuja vaivaisesti kehittyneissä varsissa. 
Kasvitautiosastossa on tarkkailtu jatkuvasti virustauteja perunakokeissa ja todettu, että varsinkin ulkomailta tuoduissa perunoissa niitä tavataan runsaasti, mm. v. 1945, jolloin osastolla oli kokeiltavana joukko Ruotsista saatuja perunalajikkeita. Useat näistä olivat melkoisesti kirjo-, kurttu- ja viiruviroosin saastuttamia.

Maatalouskoelaitoksen kasvitautiosastolle on eri tahoilta maata saatu yleensä niukasti tietoja perunan virustaudeista, joka osaltaan osoittaa, etteivät viljelijät ole pitäneet niiden aiheuttamia vahinkoja merkittävän suurina.

Hankkijan kasvinjalostuslaitoksessa Tammistossa oli tehty yksityiskohtaisempia havaintoja virustautien esiintymisestä perunakokeissa vv. 1939-43 ja 1945 (3). Virustauteja oli näinä kokeina vv. 1941-42 hyvin runsaasti. Muina havaintovuosina esiintyi virustauteja kokeissa, eräitä poikkeuksia lukuunottamatta, vain vähän.

Vuonna 1945 saatiin perunan virustaudeista tietoja Maatalouskoelaitoksen kasvinviljelys-, puutarha- ja kasvinjalostusosastoilta, useimmilta kasvinviljelyskoeasemilta sekä Suomen Suoviljelysyhdistyksen Karjalan kceasemalta. Perunan virustaudeista on saatu tietoja myös Maataloushallituksesta, jonne niitä ovat lähettäneet alueneuvojat eri tahoilta maata kasvullisuuden tilaa selostavissa kuukausiraporteissaan. Viimeksimainittujen tietojen mukaan on virustauteja todettu v. 1945 esiintyvän useissa Turun ja Porin läänin, Uudenmaan läänin sekä Hämeen läănin kunnissa. Muissa lääneissä on sen sijaan vain satunnaisesti, $1-2$ kunnassa, ilmoirettu tavatun virustauteja.

Perunan virustaudeista kerääntyneet tiedot osoittavat, että niitä tavataan Suomessa päăasiallisesti eteläosissa maata, runsaimmin Turun ja Porin, Uudenmaan ja Hämeen läăneissä. Muissa osissa Suomea ei perunan virustaudeilla näytä olevan sanottavampaa merkitystä. Maan eteläosissakaan eivät virustautien vahingot ole merkittävän suuret. Ne eivät aiheuta siellảkään perunan taantumista eli degenoroitumista siinä mielessä kuin monissa muissa perunaaviljelevissả maissa, joissa perunan siemen täytyy useilla seuduilla säännöllisesti vaihtaa uuteen virustaudeista vapaaseen joka vuosi tai ainakin $2-3$ vuoden väliajoin.

Edelläsanottu koskee varsinaisia perunanviljelyksiä. Koelaitoksilla ja koeasemilla saattaa esiintyä runsaasti virustauteja. Tämä johtuu pääasiallisesti siitä, että näille on tuotu jatkuvasti ulkomailta uutta peruna-aineistoa, joka on ollut enemmän tai vähemmän virustautista, ja joista taudit ovat vuorostaan levinneet muihin kokeiltavana oleviin lajikkeisiin. Virustautien leviảmistä kokeista laajemmalle ympäristöönsä ei sen sijaan ole tähảnastisten tietojen mukaan suuremmassa mảárir tapahtunut.

Sääsuhteilla on todettu olevan merkitystä perunan virustautien esiintymiseen Sucmessa, kuten muissakin maissa. Brummer (3) mainitsee, että kun sääsuhteet olivat 1930-luvulla ja tämän vuosikymmenen alussa lämpimien ja vähäsateisten kesien vuoksı edulliset virustautien leviämiselle, on siitä ollut seurauksena erittäin edulliset olosuhteet perunan taantumissairauksien esiintymiselle Tammiston kasvinjalostuslaitoksella. Kun sääoloissa tapahtui viime vuosira käänre, kesät muutıivat jälleen viileämmiksi ja runsassateisiksi, vähenivät virustauđit kokeissa hyvin huomattavasti. Muilta koe-elimiltä on saatu samankaltaisia tietoja.

Suomessa tavattavista perunan virustaudeista ovat mainittavia kirjoviroosi, viiruviroosi ja kurttuviroosi. Näistä ovat kirjoviroosin aiheuttamat vahingot Suomessa, kuten muissakin maissa vähaiset. Suurempaa vahinkoa aiheuttaa viiruviroosi silloin kun sitä runsaammin esiintyy $(2,3,15)$.

Olisi voinut odottaa, että kierreviroosi olisi levinnyt muihin perunanviljelyksiin maatalouskoelaitoksella Tikkurilassa, silloin kun tautia esiintyi runsaasti edelläselostetuissa kasvitautiosaston lajikekokeissa vv. 1924 -26. Näin ei kuitenkaan tapahtunut, vaan säilyivät muut maatalouskoelaitoksen perunanviljelykset jatkuvasti vapaina kierreviroosista, samoin kuin aucuba-viroosista. Kierreviroosista ei ole saatu viljelijöiltä muistakaan osista Suomea eikä liioin koeasemilta sellaisia ilmoituksia, jotka osoittaisivat taudilla olevan maassamme suurempaa merkitystä. Kaikesta päättäen on kierreviroosi, joka monissa maissa on pahimpia perunan virustauteja, Suomessa käytännöllisesti katsoen merkityksetön. Samaa on sanottava aucuba-viroosista.

Eri koe-elimiltä saadut tiedot perunalajikkeiden suhtautumisesta virustauteihin osoittavat, että Rosafolia on ollut kautta maan erittäin hyvin kestävä virustauteja vastaan. Se on ollut useimmilla koelaitoksilla ja koeasemilla lähes täysin vapaa virustaudeista. Virustauteihin nähden ovat havaintojen 
mukaan olleet moitteettomia tai vain lievästi alttiita myös lajikkeet King Georg V, Paul Wagner, Ostbote ja Tammiston aikainen. Siellä missä virustauteja, viiru- ja kurttuviroosia, on kokeissa runsaammin esiintynyt, ovat aikaisista lajikkeista olleet alttiita varsinkin lajikkeet Juli, Prof. Edler ja Vesijärvi. Muista lajikkeista ovat osoittautuneet näille taudeille enimmin alttiiksi lajikkeet Eigenheimer, Frühgold, Goldwährung, Magnum bonum, Preussen ja Upo-to-date.

Virustaudeista vapaat siemenperunat ovat muodostuneet eräissä maissa tärkeäksi vientiartikkeliksi sellaisiin maibin, joissa näitä taoteja esiintyy runsaasti. Tảllaisia perunaavieviä maita ovat mm. Viro, Hollanti, Alaska ja Kanada. Myös Suomella pitäisi olla hyvät luontaiset edellytykset ryhtyä harjoittamaan virustaudeista vapaan siemenperunan kasvattamista vientiä varten sellaisiin maihin, joissa tällä ıavaralla on kysyntää. Ainakin keski- ja pohjoisosat Suomea sopivat hyvin virustautipuhtaan perunansiemenen tuottamiselle.

Kaupattavan siemenperunan tarkastaminen on Suomessa määritelty Maatalousministeriön päätöksellä siemenperunan laatuvaatimuksista 31 p:ltä elok. 1945 (18), jonka mukaan siemenperuna jaotellaan kolmeen luokkaan: valio-, laatu- ja kauppasiemeneen. Valiosiemenen on oltava tarkastettu sekä kentällä että laboratoriossa. Näiden tarkastusten perusteella on meillä mahdollisuus tuottaa siemenperunaa, joka täyttää sille muissa maissa asetut ehdot. Laki siementavarain maahantuonnista, maasta viennistä ja kaupasta 9 p:ltä huhtik. 1937 (17) antaa puolestaan viranomaisille oikeuden valvoa, että perunan viennissä ei pääse tapahtumaan laittomuuksia.

Kuten alussa mainittiin ovat kirvat, erikoisesti persikkakirva (Myzodes persicae Sulz.) tärkeimpiä perunan virustautien levittäjiä. Myzodes persicaen levittämiä viruksia Euroopassa (vrt. 1, 5, 7, 12,16 ) ovat Solanum virus I4, joka aiheuttaa kierreviroosin, Solanum virus 2 (viiruviroosin aiheuttaja), Solanum virus 3 (aiheuttaa yhdessä Solanum virus $I$ : n kanssa kurttuviroosin) ja Solanum virus 9 (aucubaviroosin aiheuttaja). Kirjoviroosin aiheuttajan Solanum virus $I: n$ leviämistavoista ei olla täysin selvillä. Toisten tietojen mukaan se leviää pääasiallisesti kosketuksesta kasvista toiseen, toiset suhtautuvat tähän epäillen (5). Eräiden tietojen mukaan levittävät ripsiäiset Solanum virus $I$ :tä. Kirvat eivät sen sijaan esiinny tämän viruksen levittäjinä. Hernzen ja Proffrin (7) mukaan voivat Saksassa käytännöllisesti katsoen vain Myzodes persicae- ja Aulacorthum (Myzus) pseudosolani THEoв.-kirva levittää virustauteja pellossa. LeAchin (10) mukaan levittää Dolaris (Aphis) rhamni Boyer de Fonsc. Solanum virus 3:a. Eräiden muiden tutkimusten mukaan (vert. 1, 17) voivat perunan viruksia levittää myös muut kirvalajit sekä muutamat lehtikemppien, kaskaiden, ripsiäisten ja nurmiluteiden ryhmiin kuuluvat lajit.

Ruotsissa suoritetut tutkimukset (13) osoittavat, että Myzodes persicaeta tavataan paitsi EteläRuotsissa, myös muissa osissa maata; pohjoisin esiintymispaikka $63^{\circ} 15^{\prime}$ pohj. leveyttä. OssIAnNILsson osoittaa myöhemmin (14), että tätä kirvaa tavataan kasvihuonekasveissa eri tahoilla maata, joissa se voi talvehtia. Samoissa tutkimuksissa tehdään selkoa myös muiden perunan virooseja levittävien hyönteisten esiintymisestä Ruotsissa.

Myzodes persicae ei ole Suomessakaan tuntematon. Herkinhermo mainitsee julkaisussaan v:lta 1944 (6), että Phrodon (Myzodes) persicaeta tavataan Suomessa pääasiallisesti kasvihuonekasveissa. Tämän julkaisun mukaan on ensimmäinen tieto lajista v:lta 1912, löydettynä Hibiscusesta Helsingistä. Samasta paikasta ja muilta paikkakunnilta Uuttamaata on Myzodes persicae löydetty myöhemmin useita kertoja erilaisista kasvihuoneiden koriste- ja vihanneskasveista. Maist. V. KAnERvo totesi kirvaa v. 1937 Otavan maamieskoulun kasvihuoneessa lähellä Mikkeliä, useissa erilaisissa kasveissa, mm. perunassa. V. 1945 on ylioppilas O. Heıк INHE rmo kirjoittajalle antamien tietojen mukaan todennut kirvaa useissa kasvitieteellisen puutarhan kasvihuonekasveissa Helsingissä.

Nykyiset tiedot Myzodes persicaesta eivät voi antaa läheskảän selvăä kuvaa tämän lajin levinneisyydestä maassamme, puhumattakaan siitä, että niiden perusteella voisi tehdä johtopäätöksiä kirvan merkityksestä perunanviruksien levittäjinä. Ne osoittavat kuitenkin, että Myzodes persicae tavataan meillä, kuten Ruotsissakin pääasiallisesti kasvihuoneissa, joissa sillä on edellytykset talvehtimiseen. Persikka- ja aprikoosipuu, joihin kirva laskee munansa, ovat Suomessa kasvihuoneissakin siksi suuria harvinaisuuksia, että niillä ei voi olla mitään osuutta tämän kirvalajin levittäjänä. Myzodes persicaen talvehtiminen Brassica-lajeissa, joka on mahdollista mm. Walesissa (4), ei myöskään voi tulla kysymykseen Suomessa, koska meillä ei viljellä talven yli vihreinä pysyviả kaalilajeja. 
Muista kirvoista, joita tavataan maamme perunanviljelyksissä ja jotka kirjallisuustietojen mukaan voivat levittää perunan viruksia, mainittakoon Doralis rhamn Boyer de Fonsc., Neomyzus circumflecsus Buckton ja Aulacorthum sp. (todennäköisesti A. solani Kalt., jota pidetään A. pseudosolani Tнеов. synonyyminä). Näistä Doralis rhamni on mainittu Heı́rnhermon julkaisussa v:1ta 1944 (5), ja tiedot muista lajeista on saatu äskettäin ed. m. julkaisun laatijalta. Muista perunoissa esiintyvistä hyöntaisistä, joita esiintyy runsaasti maamme perunapelloissa ja jotka saattaisivat tulla kysymykseen perunaviroosien levittäjinä, mainittakoon kaskaisiin kuuluva Empasca (Chlorita) flavescens F.

Perunan virustautien esiintymisen Suomessa, kuten muissakin maissa, täytyy olla riippuvainen niitä levittävistä kirvoista. Maassamme vallitsevan kylmän ilmanalan ja kasvukauden lyhyyden vuoksi ovat eđellytykset perunavirooseja levittävien kirvojen lisääntymiselle kaikkialla Suomessa ja varsinkin keski- ja pohjoisosissa maata kaikesta päätellen vähäisemmät kuin etelàisemmissä maissa ja tästä johtuen myös perunan virustautien leviämismahdollisuudet pienemmät. 